\title{
Instructional Coaching Cycles and Career and Technical Educators' TPACK
}

\author{
Megan Motto \\ York College of Pennsylvania
}

\begin{abstract}
Most professional development occurs in a large group format. In most cases, there is little to no application or continued support for teachers. Many teachers, particularly those in career and technical schools, struggle to implement new strategies related to technological, pedagogical, and content knowledge (TPACK) with this type of support. However, the literature suggests that teachers can improve their practices through sustained professional learning with a coaching peer. This study followed six secondary teachers who participated in instructional coaching cycles at a comprehensive career and technical school to improve their technological, pedagogical, and content knowledge (TPACK) in their classrooms. Results from the study support the utility of instructional coaching as a means of helping educators develop enhanced TPACK.
\end{abstract}

Keywords: career and technical education, instructional coaching, professional development, TPACK

Educators who collaborate with an instructional coach receive personalized professional learning in the areas of technological, pedagogical, and content knowledge to benefit their overall classroom instruction. Unfortunately, many educators lack access to continuous high-quality personalized learning to support their professional development. This study explores whether educators who participate in personalized, continuous professional learning through instructional coaching cycles demonstrate increased technological, pedagogical, and content knowledge.

Historically, professional development has been offered in one-size-fits-all large group instruction with little to no opportunity for application or reflection (Eisenberg et al., 2017; Jaipal-Jamani \& Figg, 2015; Tremonte, 2018). As a result, educators struggle to implement what they learn and make lasting changes in the classroom. With the addition of an instructional coach to a school, teachers receive one-on-one support for learning that is individualized. Thus, teachers are in control their own learning through practice and reflection with a colleague who possesses dedicated experience to implement instructional changes through consistent support. 
This investigation was designed to explore the answers to two questions. The first question is: What is the effect of personalized, continuous professional learning through instructional coaching cycles on technological, pedagogical, and content knowledge? The second question is: What do educators report regarding their participation in individual instructional coaching cycles? Findings from the present study inform the discussion on the impact of instructional coaching on educators' technological, pedagogical, and content knowledge.

\section{Literature Review}

\section{TPACK Framework}

Teachers have different needs regarding implementing and blending technological, pedagogical, and content knowledge into their instruction. While many efforts have been spent attempting to quantify effective teaching, one of the most consequential was proposed by Lee Shulman. In 1986, Shulman first introduced Pedagogical Content Knowledge or PCK (Shulman, 1986). PCK was described as the important connection of sharing known content through effective teaching (Jaipal-Jamani \& Figg, 2015). This concept highlighted the importance for teachers to develop pedagogical and content knowledge to assist the learner in grasping content.

PCK has since evolved into the current TPACK Framework. The TPACK model represents the connection among technological, pedagogical, and content knowledge for teaching (Mishra \& Koehler, 2006). Content Knowledge (CK) covers the concepts, theories, and practices to be taught and varies based on the course (Koehler \& Mishra, 2009). Pedagogical Knowledge (PK) includes the processes of teaching and learning, such as, lesson planning, classroom management, student assessment, and instructional strategies. Technological Knowledge (TK) includes knowledge of technology resources and the ability to adapt to continuous changes in technology products (Koehler \& Mishra, 2009).

The areas of TPACK overlap to position teachers to provide effective instruction. Pedagogical Content Knowledge (PCK) applies to how a specific content area is taught (Koehler \& Mishra, 2009). PCK allows teachers to determine how to provide instruction of the content to increase student understanding (Jaipal-Jamani \& Figg, 2015). This connection links the specific content to the curriculum, student assessment, and teaching (Koehler \& Mishra, 2009). Teachers must understand the misconceptions of the content area and assess student knowledge throughout the instruction (Jaipal-Jamani \& Figg, 2015; Koehler \& Mishra, 2009).

Technological Content Knowledge (TCK) includes understanding how technology and content impact or restrict each other (Koehler \& Mishra, 2009). While appropriate technology can enhance students' experience and build their content knowledge, researchers caution teachers that limitations may exist which could negatively impact lesson 
delivery (Koehler \& Mishra, 2009). Additionally, content curricular decisions may restrict which types of technology are available (Koehler \& Mishra, 2009). For example, a math lesson may be better suited for paper and pencil rather than forcing the content into a digital platform that does not support the composition of math expressions.

Technological Pedagogical Knowledge (TPK) involves the comprehension of how teaching and learning are impacted by the technology used (Koehler \& Mishra, 2009). Teachers must understand how the selected technology can change the learning task to move beyond simply using the technology itself but using it to enhance instruction (Koehler \& Mishra, 2009; Zinger et al., 2017). This piece encourages teachers to look beyond the intended design of technology and customize it to increase student learning (Koehler \& Mishra, 2009).

The TPACK framework encourages a balance of technology, pedagogy, and content knowledge. This balance is vital for effective instruction and each area has an individual role which complements the others (Koehler \& Mishra, 2009). When implemented effectively, teachers can enhance instruction and advance student learning through the TPACK model (Zinger et al., 2017).

\section{Instructional Coaching}

Teaching is a demanding profession in which an educator must understand both teaching and learning. Frequent and appropriate professional development is vital to increasing a teacher's knowledge to practice effective instruction. It can be a challenge to provide personalized professional development when teachers hold different levels of knowledge and require varied practice skills through collaboration (Zinger et al., 2017). Additionally, it can be difficult to include pedagogical content knowledge learning while adding appropriate technology integration to enhance instruction during these brief and interrupted professional development sessions (Jaipal-Jamani \& Figg, 2015).

To meet the challenges of interrupted or insufficient professional development sessions, districts can employ instructional coaches who offer continued professional support after the initial instruction. Instructional coaches can provide personalized learning to teachers and create sustainable changes in pedagogy through job-embedded professional development (Eisenberg et al., 2017). The instructional coach can provide on-demand support through resources such as literacy strategies, technology integration, and other evidence-based practices through collaboration and reflection (Edutopia, 2015).

Effective instructional coaches offer reflective practices through continuous coaching cycles that support teaching and learning (Tremonte, 2018). Coaching cycles leverage adult learning theory through choice, motivation, and collaboration (Eisenberg et al., 2017). Many coaches follow the "Before, During, After" (BDA) cycle when working oneon-one with teachers (Edutopia, 2015; Eisenberg et al., 2017). To begin a cycle, coaches must establish rapport and trust with teachers to make lasting changes in instruction (Edutopia, 2015; Eisenberg et al., 2017; Tremonte, 2018). The before meeting, or B, allows for conversation about the learning outcomes where the coach mostly listens to en- 
courage metacognition (Eisenberg et al., 2017). The next step is the during, or D, which includes a variety of activities on which the coach and teacher to collaborate. The during includes evidence-based activities, such as peer observation, data collection, co-teaching and/or modeling (Eisenberg et al., 2017; Tremonte, 2018). The coaching cycle ends with the after meeting, or $\mathrm{A}$, where the coach asks reflective questions about the during piece of the cycle. It is important that the after meeting be timely, non-evaluative, and confidential to the teacher to support growth and create lasting change (Eisenberg et al., 2017). The entire cycle offers peer collaboration with embedded reflection on teaching.

Instructional coaching cycles are an essential component of professional development that meets the instructional and technological needs of individual teachers (Davis \& Currie, 2019; Eisenberg et al., 2017). Coaches collaborate with teachers to use technology to support instruction of varied content areas and meet learning outcomes (Davis \& Currie, 2019). Instructional coaching allows the outcomes of professional development to be fulfilled through practice and reflection (Eisenberg et al., 2017).

There are a variety of needs that teachers have in regard to professional development. Many tasks must occur to allow for good teaching. Teachers must understand the content knowledge of theories and practices specific to a discipline. In addition, they must navigate pedagogical knowledge of how to teach, including, but not limited to, planning, classroom management, and strategies. Additionally, teachers must use and understand ever-changing technology to support student success in and out of the classroom. It is difficult for one teacher to work alone to meet the requirements of a classroom teacher and find success in this profession. The literature demonstrates that an instructional coach can provide the necessary personalized support tailored to each teacher to find the best balance of technological, pedagogical, and content knowledge through a reflective, collaborative practice.

It is particularly difficult for career and technical educators, who leave their field and enter into education without any teaching background or experience. Career and technical teachers enter the classroom as content experts without a teaching preparation program (Lange, 2020). In order to tackle the teacher retention rate, particularly for career and technical educators, the literature illustrates the importance of support through collaboration for such teaching individuals (Eisenberg et al., 2017; Lange, 2020). Collaboration with an instructional coach allows teachers to develop their practice (Richardson et al., 2019). Instructional coaching is growing as viable option for teacher support and preparation and more research is needed in this area.

\section{Methods}

\section{Population}

The participants of this study included six teachers from a comprehensive career and technical school. At the time of the study, all teacher participants taught grades nine through twelve. Their teaching experience ranged from five years through fifteen years. 
All participants collaborated with an instructional coach before the study on various aspects of technological, pedagogical, and content knowledge strategies. Due to the coaching collaboration and consistent professional development, the teachers self-rating on the areas of the TPACK survey were average to above average. As an average, the participants were most comfortable in pedagogical knowledge before beginning the study.

Participants were made eligible for this study by their election to complete an intensive instructional coaching professional development approach at their school. The school in Dauphin County, Pennsylvania serves students from the various rural, urban, and suburban districts in the county. Students apply to the school and participate in a rotation to view all 25 career and technical programs before a final selection process. Students receive a full day of instruction in both academic and career and technical courses. Most career and technical centers are considered part-time, whereas students participate in academics at a home school and are transported to another location for career and technical instruction. This school is unique to be comprehensive and include academic instruction in the same building.

The school involved in the study employs three instructional coaches. For the purpose of this study, only one instructional coach worked with the six participants. This coach has been trained through a graduate program for instructional technology, participated in micro-credentialing programs, and a statewide coaching network known as, Pennsylvania Institute for Instructional Coaching (PIIC). PIIC is a statewide resource supported through the Annenberg Foundation and Pennsylvania Department of Education (Eisenberg et al., 2017). During the time of the study, PIIC provided two, in-person statewide conferences as well as monthly local professional development opportunities at individual Intermediate Units. The coaching model is teacher-centered and focuses on a framework of evidence-based literacy practices, data collection and analysis, nonevaluative collaboration and reflection, and support for coaches through mentoring (Eisenberg et al., 2017). The instructional coach was also the researcher for this study.

\section{Instruments}

All participants completed the TPACK survey (see Appendix A) prior to participation in the coaching cycles. The survey assessed the seven areas of TPACK including, Technology Knowledge, Content Knowledge, Pedagogy Knowledge, Pedagogical Content Knowledge, Technological Pedagogical Knowledge, Technological Content Knowledge, and Technological Pedagogical Content Knowledge (Schmidt et al., 2009). The survey included open-ended questions for reflection on classroom instruction (see Appendix $B)$. The open-ended questions were created from coaching resources shared with the researcher through the PIIC coaching network (PIIC, n.d.). 


\section{Procedures}

Participants completed the TPACK survey after submission of informed consent, and all teachers participated in school-wide professional development. This professional development was planned by the professional development committee of an assistant administrative director, the building principal, and three instructional coaches based on federal and state initiatives and instructional needs. All teachers and professional staff participate in such training and instructional coaching cycles allow for individualized support after the training has concluded.

After completion of the TPACK survey, participants began scheduling before or planning meetings with the instructional coach. The planning meetings occurred at a mutually agreed upon time and location for the coach and teacher. The meetings included time to discuss the learning outcomes and lesson planning. For some lessons, multiple planning meetings occurred to prepare. The specific details for the lessons, such as, co-teaching, modeling, and/or data collection, were agreed upon by the coach and teacher. The coach asked questions related to technological, pedagogical, and content knowledge to assist the teacher in lesson planning based on the lesson plan template used in the building.

The during meeting, or lesson, included classroom instruction to implement the learning outcomes planned in the before, or planning, meeting. The during lesson incorporated technological, pedagogical, and content knowledge through different collaborative strategies, such as co-teaching, Jigsaw, and online discussion boards. Some lessons included explicit modeling of a strategy or technological tool by the instructional coach with the students. The teacher viewed the modeling and took independent notes on how the strategy was implemented with student engagement and classroom management. Other lessons included a co-taught lesson by the coach and teacher as determined through the before conversation. The co-teaching model allows for the coach and teacher to share responsibilities of the lesson and support one another to encourage student engagement through the TPACK framework. Still other lessons included data collection by the coach during instruction by the teacher. The data collection tool was created by the teacher and coach and agreed upon in the before meeting and included one focus area of instruction, such as wait time, student participation, or on-task and off-task behaviors.

The after, or reflection, meeting occurred in a timely manner following the lesson. The reflection included open-ended questions from the instructional coach to encourage metacognition on the lesson from the teacher. The questions may be prepared in advance by the coach but are used only as a guide for reflective conversation. The teacher dictates conversation based on their needs and the conversation is organic. The coach and teacher reviewed student feedback, assessment data, and the lesson goals in the reflection while noting suggestions for future lessons. 


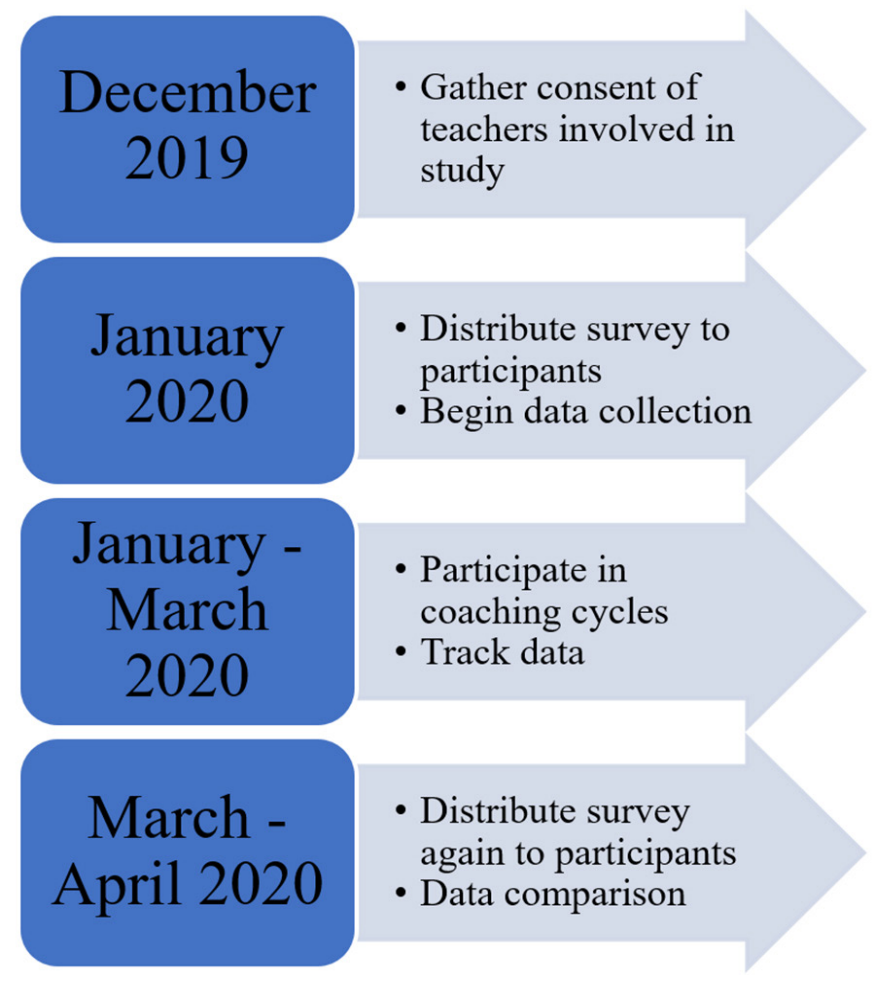

Figure 1. Research Protocol

Each participant was scheduled to engage in this cycle at least twice. Following the completion of the second coaching cycle, participants completed the TPACK survey a second time. The results from the first and second completion were compared to review the impact of the instructional coaching cycles on the TPACK framework. Due to the COVID-19 shutdown of schools, not all participants participated in two complete coaching cycles.

\section{Data Analysis and Results}

A paired sample $t$-test was employed to compare the pre- and post-PCK scores of the participants. The descriptive data that identified the changes in participants' PCK scores as recorded by the pre- and post-field experience PCK surveys are displayed in Table 1.

Table 1. Pre- and Post-PCK Results

\begin{tabular}{lccc}
\hline Measure & N & Mean & SD \\
\hline Pre-PCK & 6 & 3.25 & 0.39 \\
Post-PCK & 6 & 3.95 & 0.52 \\
\hline
\end{tabular}

A paired sample $t$-test was employed to compare the pre- and post-TCK scores of the participants. The descriptive data that identified the changes in participants' TCK scores as recorded by the pre- and post-field experience TCK surveys are displayed in Table 2. 
Table 2. Pre- and Post-TCK results

\begin{tabular}{lccc}
\hline Measure & N & Mean & SD \\
\hline Pre-TCK & 6 & 3.45 & 0.46 \\
Post-TCK & 6 & 3.91 & 0.37 \\
\hline
\end{tabular}

A paired sample $t$-test was employed to compare the pre- and post-TPK scores of the participants. The descriptive data that identified the changes in participants' TPK scores as recorded by the pre- and post-field experience TPK surveys are displayed in Table 3.

Table 3. Pre- and Post-TPK Results

\begin{tabular}{lccc}
\hline Measure & N & Mean & SD \\
\hline Pre-TPK & 6 & 3.64 & 0.51 \\
Post-TPK & 6 & 4.24 & 0.56 \\
\hline
\end{tabular}

A paired sample $t$-test was employed to compare the pre- and post-TPACK scores of the participants. The descriptive data that identified the changes in participants' TPACK scores as recorded by the pre- and post-field experience TPACK surveys are displayed in Table 4.

Table 4. Pre- and Post-TPACK Results

\begin{tabular}{lccc}
\hline Measure & N & Mean & SD \\
\hline Pre-TPACK & 6 & 3.62 & 0.66 \\
Post-TPACK & 6 & 3.91 & 0.53 \\
\hline
\end{tabular}

The results of a paired-sample $t$-test demonstrated that the mean score for Post-PCK samples were not significantly higher than the mean score of the Pre-PCK participants. The paired samples $t$-test indicated a $p$-value of 0.01 , which is equal to the $p=$ 0.05 threshold, confirming the null hypothesis (see Table 5).

Table 5. Paired-sample $t$-test comparison of the Pre- and Post-treatment PCK scores

\begin{tabular}{lcccc}
\hline Measure & df & MD & $\boldsymbol{t}$ & $\boldsymbol{p}$ \\
\hline Pre- and Post-PCK Scores & 5 & 0.7 & -2.73 & 0.01 \\
\hline
\end{tabular}

The results of a paired-sample $t$-test demonstrated that the mean score for Post-TCK samples were not significantly higher than the mean score of the Pre-TCK participants. The paired samples $t$-test indicated a $p$-value of 0.05 , which is equal to the $p=$ 0.05 threshold, confirming the null hypothesis (see Table 6). 
Table 6. Paired-sample $t$-test comparison of the Pre- and Post-treatment TCK scores

\begin{tabular}{lcccc}
\hline Measure & df & MD & $\boldsymbol{t}$ & $\boldsymbol{p}$ \\
\hline Pre- and Post-TCK Scores & 5 & 0.46 & -1.71 & 0.05 \\
\hline
\end{tabular}

The results of a paired-sample $t$-test demonstrated that the mean score for Post-TPK samples were not significantly higher than the mean score of the Pre-TPK participants. The paired samples $t$-test indicated a $p$-value of 0.05 , which is equal to the $p=$ 0.05 threshold, confirming the null hypothesis (see Table 7).

Table 7. Paired-sample $t$-test comparison of the Pre- and Post-treatment TPK scores

\begin{tabular}{lcccc}
\hline Measure & df & MD & $\boldsymbol{t}$ & $\boldsymbol{p}$ \\
\hline Pre- and Post-TPK Scores & 5 & 0.6 & -1.75 & 0.05 \\
\hline
\end{tabular}

The results of a paired-sample $t$-test demonstrated that the mean score for Post-TPACK samples were not significantly higher than the mean score of the Pre-TPACK participants. The paired samples $t$-test indicated a $p$-value of 0.22 , which is equal to the $p=$ 0.05 threshold, confirming the null hypothesis (see Table 8 ).

Table 8. Paired-sample $t$-test comparison of the Pre- and Post-treatment TPACK scores

\begin{tabular}{lcccc}
\hline Measure & df & MD & $\boldsymbol{t}$ & $\boldsymbol{p}$ \\
\hline Pre- and Post-TPACK Scores & 5 & 0.29 & -0.77 & 0.22 \\
\hline
\end{tabular}

An open-ended questionnaire was employed to allow educators to report on their experience with individual instructional coaching cycles. The researcher used Google Forms to gather the survey results into a Google Sheet. The responses for each question were compared to find any themes. Two themes were identified from the qualitative survey.

The first theme that educators reported was increased student engagement in the lessons planned and implemented during a coaching cycle. Students practiced reading, writing, speaking, and listening skills with one another and the teacher. Educators reported that students were more responsive during instruction and communicated with one another through in-person conversation or digital tools. Students were engaged in new methods with varying strategies. The responses from the survey are illustrated in Table 9. 
Table 9. Survey Responses on Student Engagement

\begin{tabular}{ll}
\hline Survey Question & Response \\
\hline $\begin{array}{l}\text { How are you going to } \\
\text { use this information to } \\
\text { drive future lessons? }\end{array}$ & $\begin{array}{l}\text { Participant 2: "The students talking to each other and } \\
\text { hearing other students' ideas helped with the vocabulary } \\
\text { words. It helps students communicate online as well as } \\
\text { learn to talk with one another using a discussion board." }\end{array}$ \\
$\begin{array}{ll}\text { What did you learn from } \\
\text { this experience? }\end{array}$ & $\begin{array}{l}\text { Participant 5: "I have learned to be more open to exploring } \\
\text { the use of technology for both content instruction and stu- } \\
\text { dent assessment. While the process of learning and utiliz- } \\
\text { ing new technology in the classroom can be intimidating, it } \\
\text { can be rewarding to see students become more engaged } \\
\text { in the content when they might otherwise have been less } \\
\text { engaged when using more traditional instructional meth- } \\
\text { ods." }\end{array}$ \\
$\begin{array}{l}\text { What evidence did you } \\
\text { see or hear that the } \\
\text { students met your goal, } \\
\text { partially met your goal, } \\
\text { or did not meet your } \\
\text { goal? }\end{array}$ & $\begin{array}{l}\text { Participant 3: "Students wrote responses to reading pas- } \\
\text { sages as well as verbally shared thoughts." }\end{array}$ \\
\hline
\end{tabular}

The second theme that appeared in the survey was increased teacher confidence with instruction. Educators were more willing to adapt lessons or try new ideas with a coaching peer. They reported increased confidence in trying new strategies or digital tools with students. Through the coaching cycle, they learned how to add new technology as appropriate to differentiate student needs. The responses from the survey are illustrated in Table 10.

Table 10. Survey Responses on Teacher Confidence

\begin{tabular}{ll}
\hline Survey Question & Response \\
\hline $\begin{array}{l}\text { What did you learn from } \\
\text { this experience? }\end{array}$ & $\begin{array}{l}\text { Participant 4: "I tried new things with this lesson so I } \\
\text { gained a little confidence." }\end{array}$ \\
$\begin{array}{ll}\text { What did you learn from } \\
\text { this experience? }\end{array}$ & $\begin{array}{l}\text { Participant 6: "I am learning a lot about ways to adapt les- } \\
\text { sons and incorporate technology." }\end{array}$ \\
$\begin{array}{ll}\text { What did you learn from } \\
\text { this experience? }\end{array}$ & $\begin{array}{l}\text { Participant 1: "I gained a better understanding for the pur- } \\
\text { pose and use of formative assessments." }\end{array}$ \\
\hline
\end{tabular}




\section{Conclusion}

The results of this study show that the career and technical educators who participated in individualized instructional coaching cycles benefited in their overall classroom instruction. The individualized and continuous professional learning focused on technological, pedagogical, and content knowledge in accordance with the needs of the educator. Analysis of participants' TPACK survey responses before and after the coaching cycles showed growth in all areas. After completion of the individualized coaching cycles, participants reported higher levels of confidence in overall TPACK, particularly in how technology impacts content knowledge and pedagogy.

The TPACK survey results show that the entire coaching cycle made an impact on student engagement and teacher confidence. Teachers were more willing to try new strategies or technology tools in the classroom that were originally introduced in large group professional development sessions. This is consistent with Eisenberg et al. (2017), who note that instructional coaching allows the outcomes of professional development to be fulfilled through practice and reflection.

Educators understood the importance of reflection, but as Jaipal-Jamani and Figg (2015) share, they were also constrained by the need to complete other professional responsibilities and learning goals. There are a number of demands on teachers but coaching allows for personalized growth at the appropriate time for the teacher (Eisenberg et al., 2017; Jaipal-Jamani \& Figg, 2015). To develop technological, pedagogical, and content knowledge effectively, proper reflection is needed and is encouraged with an instructional coach. The literature shows the importance of reflection in developing instructional knowledge (Eisenberg et al., 2017, Tremonte, 2018). This study further showed that the instructional coach can provide on-demand support through resources such as literacy strategies, technology integration, and other evidence-based practices through collaboration and reflection (Edutopia, 2015). Reflection constantly occurs when collaborating with a coaching peer while also fitting the needs of the individual teacher to support growth and create instructional change (Eisenberg et al., 2017). This study showed that participants grew more confident and made changes in their instructional practice to benefit students.

Using technology in the classroom can be stressful or intimidating. Zinger et al. (2017) comment that educators "need to move beyond focusing on technology itself and focus on teaching with technology" (p. 389). The continuous practice and reflection with a coaching peer allow for more effective technology use in the classroom. Educators in this study commented that technology provided more opportunities for students to engage with the content and one another when compared with traditional methods.

This study was limited to a small sample size of six high school educators. The participants possessed technological and pedagogical knowledge prior to the research and have worked with instructional coaches in the past. This may have resulted in the higher scores on the TPACK survey. Another limitation includes that the study was shortened due to the COVID-19 shutdown of schools and businesses. As a result, not all partic- 
ipants completed two full coaching cycles. The positive findings of the present study affirm the strong potential of instructional coaching as a mechanism for enhancing educators' TPACK. Future research could compare coached educators to non-coached educators. Additionally, future studies could compare career and technical educators to traditional academic educators. This study only included educator responses on the survey. Future studies could also include student surveys to compare with the teacher surveys. 


\section{References}

Davis, E. and Currie, B. (2019). Tech integration comes alive through coaching. ASCD Express, 14(17). Retrieved from http://www.ascd.org/ascd-express/home.aspx

Edutopia. (2015, June 23). Making technology work. Retrieved from https://www.edutopia.org/practice/instructional-coaching-driving-meaningful-tech-integration

Eisenberg, E., Eisenberg, B., Medrich, E., and Charner, I. (2017). Instructional coaching in action: An integrated approach that transforms thinking, practice, and schools. Alexandria, VA: ASCD.

Jaipal-Jamani, K. \& Figg, C. (2015). A case study of a TPACK-based approach to teacher professional development: Teaching science with blogs. Contemporary Issues in Technology and Teacher Education, 15(2), 161-200.

Koehler, M. J., \& Mishra, P. (2009). What is technological pedagogical content knowledge? Contemporary Issues in Technology and Teacher Education, 9(1), 60-70.

Lange, S. W. (2020). Examining career and technical education practioner preparation and professional development needs. (Doctor of Education). Illinois State University.

Mishra, P., \& Koehler, M. (2006). Technological pedagogical content knowledge: A framework for teacher knowledge. The Teachers College Record, 108(6), 10171054.

Pennsylvania Institute for Instructional Coaching. (n.d.) What are typical behaviors of the BDA cycle of coaching when coaches and teachers meet? Retrieved from: https://instituteforinstructionalcoaching.org/

Richardson, G., Yost, D., Conway, T., Magagnosc, A., and Mellor, A. (2019). Using instructional coaching to support student teacher-cooperating teacher relationships. Action in Teacher Education, 42(3), 271-289.

Schmidt, D. A., Baran, E., Thompson A. D., Koehler, M. J., Mishra, P. \& Shin, T. (200910). Technological pedagogical content knowledge (TPACK): The development and validation of an assessment instrument for preservice teachers. Journal of Research on Technology in Education, 42(2), 123-149.

Shulman, L. S. (1986). Those who understand: Knowledge growth in teaching. Educational Researcher, 15(2), 4-14.

Tremonte, A. (2018). Why teacher-driven coaching looks different for every learner. Retrieved from https://www.edsurge.com/news/2018-04-13-why-teacher-drivencoaching-looks-different-for-every-learner 
Zinger, D., Naranjo, A., Amador, I., Gilbertson, N., and Warschauer, M. (2017). A design-based research approach to improving professional development and teacher knowledge: The case of the Smithsonian learning lab. Contemporary Issues in Technology and Teacher Education, 17(3), 388-410. 


\section{Appendix A - TPACK Survey}

\section{TPACK Survey}

Thank you for taking time to complete this questionnaire. Please answer each question to the best of your knowledge. Your thoughtfulness and candid responses will be greatly appreciated. Your individual name or identification number will not at any time be associated with your responses. Your responses will be kept completely confidential and will not influence your evaluation.

Technology is a broad concept that can mean a lot of different things. For the purpose of this questionnaire, technology is referring to digital technology/technologies. That is, the digital tools we use such as computers, laptops, iPads, handhelds, interactive whiteboards, software programs, etc. Please answer all of the questions and if you are uncertain of or neutral about your response you may always select "Neither Agree or Disagree".

1. TK (Technology Knowledge)

Mark only one oval per row.

\begin{tabular}{|c|c|c|c|c|c|}
\hline & $\begin{array}{l}\text { Strongly } \\
\text { Agree }\end{array}$ & Agree & $\begin{array}{c}\text { Neither Agree or } \\
\text { Disagree }\end{array}$ & Disagree & $\begin{array}{l}\text { Strongly } \\
\text { Disagree }\end{array}$ \\
\hline $\begin{array}{l}\text { I know how to solve my } \\
\text { own technical problems. }\end{array}$ & & & & & \\
\hline $\begin{array}{l}\text { I can learn technology } \\
\text { easily. }\end{array}$ & & & & & \\
\hline $\begin{array}{l}\text { I keep up with important } \\
\text { new technologies. }\end{array}$ & & & & & \\
\hline $\begin{array}{l}\text { I frequently play around the } \\
\text { technology. }\end{array}$ & & & & & \\
\hline $\begin{array}{l}\text { I know about a lot of } \\
\text { different technologies. }\end{array}$ & & & & & \\
\hline $\begin{array}{l}\text { I have the technical skills I } \\
\text { need to use technology. }\end{array}$ & & & & & \\
\hline
\end{tabular}

2. CK (Content Knowledge)

Mark only one oval per row.

I have sufficient knowledge
about mathematics.
I can use a mathematical
way of thinking.
I have various ways and
undegies of developing my
mathematics.
I have sufficient knowledge
about social studies.
I can use a historical way of
thinking.
I have various ways and
strategies of developing my
understanding of social
studies.
I have sufficient knowledge
about science.
I can use a scientific way of
thinking.
I have various ways and
strategies of developing my
understanding of science.
I have sufficient knowledge
about literacy.
I can use a literary way of
thinking.
I have various ways and
undegies of developing my
uisagree


3. PK (Pedagogical Knowledge) Mark only one oval per row.

I know how to assess
student performance in a
classroom.
I can adapt my teaching
based-upon what students
currently understand or do
not understand.
I can adapt my teaching
style to different learners.
I can assess student
learning in multiple ways.
I can use a wide range of
teaching approaches in a
classroom setting.
I am familiar with common
student understandings and
misconceptions.
I know how to organize and
maintain classroom
management.

4. PCK (Pedagogical Content Knowledge)

Mark only one oval per row.

I can select effective
teaching approaches to
guide student thinking and
learning in mathematics.
I can select effective
teaching approaches to
guide student thinking and
learning in literacy.
I can select effective
teaching approaches to
guide student thinking and
learning in science.
I can select effective
teaching approaches to
guide student thinking and
learning in social studies.

5. TCK (Technological Content Knowledge)

Mark only one oval per row.

I know about technologies
that I can use for
understanding and doing
mathematics.
I know about technologies
that I can use for
understanding and doing
literacy.
I know about technologies
that I can use for
understanding and doing
science.
I know about technologies
that I can use for
understanding and doing
social studies.


6. TPK (Technological Pedagogical Knowledge)

Mark only one oval per row.

I can choose technologies
that enhance the teaching
approaches for a lesson.
I can choose technologies
that enhance students'
learning for a lesson.
My teacher education
program has caused me to
think more deeply about
how technology could
influence the teaching
approaches I use in my
classroom.
I am thinking critically about
how to use technology in
my classrom.
I can adapt the use of the
technologies that I am
learning about to different
teaching activities.
I can select technologies to
use in my classroom that
enhance what I teach, how
I teach and what students
learn.
I can use strategies that
combine content.
technologies and teaching
approaches that I learned
about in my coursework in
my classroom.
I can provide leadership in
helping others to coordinate
the use of content.
technologies and teaching
approaches at my school
andlor district.
I can choose technologies
that enhance the content
for a lesson.
Disagree

7. TPACK (Technology Pedagogy and Content Knowledge) Mark only one oval per row.

I can teach lessons that
appropriately combine
mathematics, technologies
and teaching approaches.
I can teach lessons that
appropriately combine
literacy, technologies and
teaching approaches.
I can teach lessons that
appropriately combine
science, technologies and
teaching approaches.
I can teach lessons that
appropriately combine
social studies, technologies
and teaching approaches.




\section{Appendix B - Open-ended Questions Added to TPACK Survey}

- What evidence did you see or hear that the students met your goal, partially met your goal, or did not meet your goal?

- What additional resources would you need to make this lesson more effective?

- How are you going to use this information to drive future lessons?

- What personal learnings did you gain from this experience?

- How did technology affect student engagement or learning in the lesson? 